\title{
Factors limiting the open-circuit voltage in microcrystalline silicon solar cells
}

\author{
M. Nath ${ }^{1, a}$, S. Chakraborty ${ }^{1}$, E.V. Johnson ${ }^{2}$, A. Abramov ${ }^{2}$, P. Roca i Cabarrocas ${ }^{2}$, and P. Chatterjee ${ }^{1}$ \\ 1 Energy Research Unit, Indian Association for the Cultivation of Science, 700032 Kolkata, India \\ 2 Laboratoire de Physique des Interfaces et des Couches Minces, École Polytechnique, CNRS, 91128 Palaiseau, France
}

Received: 18 March 2011 / Accepted: 22 September 2011

Published online: 17 November 2011

\begin{abstract}
In studying photovoltaic devices made with silicon thin films and considering them according to their grain size, it is curious that as the crystalline fraction increases, the open-circuit voltage $\left(V_{o c}\right)$ - rather than approaching that of the single-crystal case - shows a decline. To gain an insight into this behavior, observed in hydrogenated microcrystalline silicon $(\mu \mathrm{c}-\mathrm{Si}: \mathrm{H})$ solar cells prepared under a variety of deposition conditions, we have used a detailed electrical-optical computer modeling program, ASDMP. Two typical $\mu$ c-Si:H cells with low $(\sim 79 \%)$ and higher $(\sim 93 \%)$ crystalline volume fractions $\left(F_{c}\right)$, deposited in our laboratory and showing this general trend, were modeled. From the parameters extracted by simulation of their experimental current density - voltage and quantum efficiency characteristics, it was inferred that the higher $F_{c}$ cell has both a higher band gap defect density as well as a lower band gap energy. Our calculations reveal that the proximity of the quasi-Fermi levels to the energy bands in cells based on highly crystallized $\mu \mathrm{c}-\mathrm{Si}: \mathrm{H}$ (assumed to have a lower band gap), results in both higher free and trapped carrier densities. The trapped hole population, that is particularly high near the P/I interface, results in a strong interface field, a collapse of the field in the volume, and hence a lower open-circuit voltage. Interestingly enough, we were able to fabricate fluorinated $\mu \mathrm{c}-\mathrm{Si}: \mathrm{H}: \mathrm{F}$ cells having $100 \%$ crystalline fraction as well as very large grains, that violate the general trend and show a higher $V_{o c}$. Modeling indicates that this is possible for the latter case, as also for a crystalline silicon PN cell, in spite of a sharply reduced band gap, because the lower effective density of states at the band edges and a sharply reduced gap defect density overcome the effect of the lower band gap.
\end{abstract}

\section{Introduction}

When considering the full spectrum of thin film Si-based photovoltaic technologies and ranking them according to their crystalline volume fraction $\left(F_{c}\right)$, it is remarked that the open-circuit voltage $\left(V_{o c}\right)$ decreases with increasing $F_{c}$. This has been observed by various groups working with cells fabricated from hydrogenated microcrystalline silicon ( $\mu \mathrm{c}-\mathrm{Si}: \mathrm{H})$ films deposited by a variety of deposition techniques [1-4] (Fig. 1). This fact hinders the further development of thin-film silicon photovoltaics as the loss in $V_{o c}$ offsets any gain in the short-circuit current density $\left(J_{s c}\right)$, prompting Mai et al. $[1,2]$ to remark that the optimum $\mu \mathrm{c}-\mathrm{Si}: \mathrm{H}$ solar cells are always obtained with intermediate crystallinity. The physical reason behind this loss in $V_{o c}$ is not immediately clear, as the maximum impact of the most obvious factor (the smaller band gap) is diminished by the example of single-crystal silicon (c-Si), which possesses the smallest band gap but a higher $V_{o c}$

a e-mail: madhumitanath_21@yahoo.co.in than cells with smaller grains (Fig. 1). Since the observation is a decrease of $V_{o c}$ with increasing $F_{c}$ of the $\mu \mathrm{c}-\mathrm{Si}: \mathrm{H}$ absorber from $60 \%$ to over $90 \%$, while a mono-crystalline silicon $\mathrm{PN}$ cell has an appreciably higher $V_{o c}$, it is expected that a missing link maybe found - a limiting case of a very well-crystallized and large grained $\mu \mathrm{c}-\mathrm{Si}: \mathrm{H}$ material - which when used as the absorber layer in a solar cell, should yield an open-circuit voltage intermediate between that of a cell based on a highly-crystallized $\mu \mathrm{c}-\mathrm{Si}: \mathrm{H}$ absorber and the considerably higher $V_{o c}$ of a mono-c-Si PN cell. The parameters characterizing such a cell, as deduced from modeling, should then help us understand how the open-circuit voltage of $\mu \mathrm{c}-\mathrm{Si}: \mathrm{H}$ solar cells can be made to approach the higher $V_{o c}$ that characterizes single crystal silicon cells.

As a matter of fact we have found that solar cells based on fluorinated $\mu \mathrm{c}-\mathrm{Si}: \mathrm{H}[5]$ ( $\mu \mathrm{c}-\mathrm{Si}: \mathrm{H}: \mathrm{F})$, with a very high $F_{c}$ as well as a significant fraction of large grains $\left(F_{l g}\right)$, appear to violate the general rule (Fig. 1 - in fact this figure shows, besides the typical $V_{o c}$ of classical diffused junction c-Si solar cells [6], also the $V_{o c}$ 's of "heterojunction 
Table 1. Comparison between the measured and simulated solar cell output parameters of the PIN devices having low and intermediate crystalline volume fraction $\left(F_{c}\right) \mu \mathrm{c}-\mathrm{Si}: \mathrm{H}$ as the intrinsic layer. $F_{l q}$ gives the fraction of large grains in the I-layer. Also compared are the measured and modeled output parameters of the highly crystallized, large grained $\mu \mathrm{c}-\mathrm{Si}: \mathrm{H}: \mathrm{F}$ cell.

\begin{tabular}{cccccccc}
\hline Sample & $F_{c}(\%)$ & $F_{l g}(\%)$ & & $\begin{array}{c}J_{s c} \\
\left(\mathrm{~mA} / \mathrm{cm}^{2}\right)\end{array}$ & $\begin{array}{c}V_{o c} \\
(\mathrm{~V})\end{array}$ & $F F$ & $\begin{array}{c}\text { Efficiency } \\
(\%)\end{array}$ \\
\hline$\mu \mathrm{c}-\mathrm{Si}: \mathrm{H}$ & \multirow{2}{*}{79} & \multirow{2}{*}{0} & Expt & 16.76 & 0.54 & 0.687 & 6.22 \\
$(\mathrm{~A})$ & & & Model & 16.76 & 0.54 & 0.685 & 6.20 \\
\hline$\mu \mathrm{c}-\mathrm{Si}: \mathrm{H}$ & \multirow{2}{*}{93} & \multirow{2}{*}{27} & Expt & 19.94 & 0.46 & 0.631 & 5.79 \\
$(\mathrm{~B})$ & & & Model & 19.85 & 0.45 & 0.643 & 5.73 \\
\hline$\mu \mathrm{c}-\mathrm{Si}: \mathrm{H}: \mathrm{F}$ & \multirow{2}{*}{$\sim 100$} & \multirow{2}{*}{50} & Expt & 23.20 & 0.523 & 0.680 & 8.30 \\
& & & Model & 22.93 & 0.526 & 0.704 & 8.49 \\
\hline
\end{tabular}

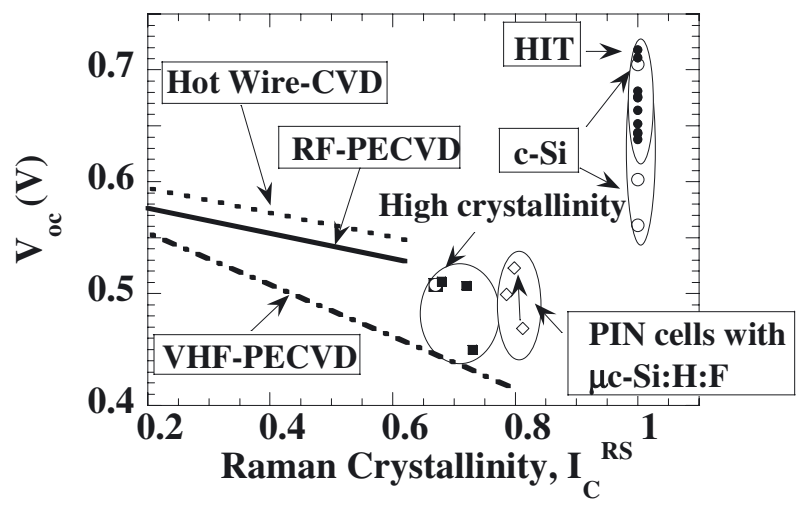

Fig. 1. Results taken from various literature sources $[1-4]$ indicate the general trend of a decrease in the open-circuit voltage of $\mu \mathrm{c}-\mathrm{Si}$ :H thin film PIN cells, with increase of the Raman crystallinity of the films. We also show an exception where the $V_{o c}$ actually increases [5] in a highly crystallized $\mu \mathrm{c}-\mathrm{Si}: \mathrm{H}: \mathrm{F}$ cell, specially after interface treatment (indicated by the arrow) Also shown in the figure are typical $V_{o c}$ 's of classical diffused junction c-Si solar cells (open circles - 5, Green's ref), of a "heterojunction with intrinsic thin layer (HIT)" cell on a P-type c-Si substrate [7] and of a HIT cell on N-type c-Si [8] (closed circles).

with intrinsic thin layer (HIT)" cells on P-type [7] and N-type [8] c-Si substrates, for completeness). A material containing large grains is a dense material with low oxygen content, which can be obtained when using $\mathrm{SiF}_{4}$ based plasma processes [5]. We then chose two of a series of typical (that follow the general rule of decreasing $V_{o c}$ with increasing $F_{c}-$ Fig. 1) $\mu \mathrm{c}-\mathrm{Si}: \mathrm{H}$ cells, as well as a cell based on $\mu \mathrm{c}-\mathrm{Si}: \mathrm{H}: \mathrm{F}$, for modeling using the detailed electricaloptical computer code ASDMP $[9,10]$. Using parameters extracted by simulating the output experimental characteristics of the $\mu \mathrm{c}-\mathrm{Si}: \mathrm{H}$ thin film solar cells with absorber layers of different degrees of crystallinity, we identify in this article, the parameters responsible for the general decline of $V_{o c}$ in such cells with increasing crystalline volume fraction (Fig. 1). Moreover by simulating the output characteristics of the $\mu \mathrm{c}-\mathrm{Si}: \mathrm{H}: \mathrm{F}$ solar cells, we could identify the critical parameters which prevent $\mu \mathrm{c}-\mathrm{Si}: \mathrm{H}$ solar cells in achieving the higher $V_{o c}$ attainable in c-Si PN cells.

\section{Experimental details}

Microcrystalline PIN solar cells having the structure textured $\mathrm{ZnO} / \mathrm{P}-\mu \mathrm{c}-\mathrm{Si}: \mathrm{H} / \mathrm{I}-\mu \mathrm{c}-\mathrm{Si}: \mathrm{H} / \mathrm{N}-\mathrm{a}-\mathrm{Si}: \mathrm{H} /$ Aluminum have been deposited in a multiplasma monochamber radio-frequency plasma-enhanced chemical vapor deposition (RF-PECVD) reactor [11]. Two sets of $\mu \mathrm{c}-\mathrm{Si}: \mathrm{H}$ solar cells have been deposited with $\sim 60 \mathrm{~mW} / \mathrm{cm}^{2}$ of $\mathrm{RF}$-power at $175^{\circ} \mathrm{C}$. We employed different ratios of silane to hydrogen flow rates during the intrinsic layer deposition for the two sets $-\mathrm{SiH}_{4}: \mathrm{H}_{2}=6: 200$ (cell A) and $\mathrm{SiH}_{4}: \mathrm{H}_{2}=4: 200$ (cell B) [4], which results in different total crystalline volume fraction $\left(F_{c}\right)$ and large grain fraction $\left(F_{l g}\right)$ in the samples (Tab. 1). A third set has a fluorinated $\mu \mathrm{c}-\mathrm{Si}: \mathrm{H}$ intrinsic (I)-layer (Tab. 1), where the I-layer was deposited from a $\mathrm{SiF}_{4}, \mathrm{H}_{2}$ and $\mathrm{Ar}$ gas mixture [5]. The respective flow rates of the above gases were 3,3 and $70 \mathrm{sccm}$ respectively. The deposition pressure was 2.7 torr, the RF power $440 \mathrm{~mW} \mathrm{~cm}^{-2}$ and the substrate temperature $200{ }^{\circ} \mathrm{C}$. The $\mu \mathrm{c}-\mathrm{Si}: \mathrm{H}$ P-layer and the a-Si:H N-layer were deposited in a second multi-chamber reactor, using TMB and $\mathrm{PH}_{3}$ as dopant gases, and thus necessitating a vacuum break between the doped and intrinsic layers. A hydrogen plasma treatment (after both air breaks) was applied towards passivation of the $\mathrm{P} / \mathrm{I}$ and $\mathrm{I} / \mathrm{N}$ defects. The $\mathrm{P}$ - and N-layers were deposited using similar conditions for all cells. It maybe pointed out that a series of cells having similar output characteristics were deposited during each run and that the values cited in Table 1 are representative of each series.

The composition of the films was obtained from the Bruggeman effective medium approximation modeling [12] of the pseudo-dielectric function of the films, deduced from spectroscopic ellipsometry measurements. This approach has been shown to be well adapted to the modeling of $\mu \mathrm{c}-\mathrm{Si}$ films [13]. In this approach we used as components for the model the dielectric functions of (i) amorphous silicon, (ii) voids to take into account the porosity of the films; (iii) small grain $\mu \mathrm{c}-\mathrm{Si}$ and (iv) large grain $\mu \mathrm{c}-\mathrm{Si}$ material produced by Chemical vapor deposition (CVD) at $\sim 650{ }^{\circ} \mathrm{C}$ [14]. In Table 1 we report the values of the total crystalline fraction $F_{c}$ (which is the sum of the small grain and large grain fractions) and the large grain fraction 
$F_{l g}$, for the two sets of $\mu \mathrm{c}-\mathrm{Si}: \mathrm{H}$ samples and those of $\mu \mathrm{c}-\mathrm{Si}: \mathrm{H}: \mathrm{F}$. Indeed, achieving a high value of $F_{l g}$ in the case of $\mu \mathrm{c}-\mathrm{Si}: \mathrm{H}: \mathrm{F}$, indicates that the films obtained by PECVD at $175{ }^{\circ} \mathrm{C}$ have a grain size similar to that of polycrystalline layers produced by $\mathrm{CVD}$ at $\sim 650{ }^{\circ} \mathrm{C}[14]$. The greatly improved spectral response at long wavelengths also confirms the very high crystalline volume fraction of $\mu \mathrm{c}-\mathrm{Si}: \mathrm{H}: \mathrm{F}[5]$.

\section{Simulation model}

The one-dimensional electrical-optical model ASDMP $[9,10]$ (amorphous semiconductor device modeling program) used in this study solves the Poisson's equation and the two carrier continuity equations under steady state conditions for the given device structure, and yields the resulting $J-V$ characteristics and the quantum efficiency. The electrical part of the modeling program is described in references $[15,16]$. The expressions for the free and trapped charges, the recombination term, the boundary conditions and the solution technique in this program are similar to the AMPS computer program developed by McElheny et al. [17].

The gap state model used in these calculations consists of the tail states, as well as a donor-like and an acceptorlike set of Gaussian distribution functions to simulate the deep dangling bond states. The contact barrier heights for a cell with the $\mathrm{P}$-layer in contact with the $\mathrm{ZnO}$ at $x=0$ and the $\mathrm{N}$-layer in contact with aluminum at $x=L$, are taken to be $1.11 \mathrm{eV}$ and $0.2 \mathrm{eV}$, respectively. Since the activation energies of our $\mathrm{P}-\mu \mathrm{c}-\mathrm{Si}: \mathrm{H}$ and $\mathrm{N}-\mathrm{a}-\mathrm{Si}: \mathrm{H}$ layers are $0.09 \mathrm{eV}(\mathrm{P}-\mu \mathrm{c}-\mathrm{Si}: \mathrm{H}$ band gap is $1.2 \mathrm{eV})$ and $0.2 \mathrm{eV}$ respectively, this implies that no effective surface band bending has been assumed at the $\mathrm{ZnO} / \mathrm{P}-\mu \mathrm{c}-\mathrm{Si}: \mathrm{H}$ contact and the $\mathrm{N}-\mathrm{a}-\mathrm{Si}: \mathrm{H} / \mathrm{Al}$ contact is ohmic. The assumption of no band bending at the $\mathrm{ZnO} / \mathrm{P}-\mu \mathrm{c}-\mathrm{Si}: \mathrm{H}$ interface originates from the fact that we had to assume an extremely high P-layer doping density $\left(3 \times 10^{19} \mathrm{~cm}^{-3}\right)$, therefore also a very high $\mathrm{P}$-layer defect density, to simulate these cells. This means that when the TCO and the P-layer are put in contact, the trapped electrons on the $\mathrm{P}-\mu \mathrm{c}-\mathrm{Si}: \mathrm{H}$ side are confined to a very thin layer on the $\mathrm{P}$-side, resulting in a very high surface band bending that however does not appreciably extend into the bulk of the P-layer. For the purpose of calculating the built-in potential $\left(V_{b i}\right)$ and $V_{o c}$, the bulk activation energy of the P-layer is then already achieved almost at the TCO/P interface, and the bandbending does not extend to any appreciable thickness of the P-layer.

The generation term in the continuity equations has been calculated using a semi-empirical model [18], that has been integrated into the modeling program $[9,10]$. Both specular interference effects and diffused reflectances and transmittances due to interface roughness are taken into account. It is now well-recognized that TCO texture is a key issue in increasing cell efficiency, as it reduces optical reflection loss and greatly increases light diffusion. Weakly absorbed radiation, when scattered, can be partly absorbed in a high refractive index layer, such as amorphous or micro-crystalline $\mathrm{Si}(n \approx 3.7)$, due to total internal reflection at the interfaces giving rise to optical confinement. However because of the broad distribution of grain size and shape, the interaction between the multilayer device and incident light is very complex and so, rather than a rigorous three-dimensional electromagnetic treatment of the diffused radiation, a rather sophisticated semi-empirical model [18], was integrated $[9,10]$ with the electrical model $[15,16]$. Here diffused reflectances and transmittances, are derived from angular resolved photometric measurements, and used as input parameters. In the model, the electromagnetic field's specular reflection and transmission are assumed proportional to the Fresnel coefficients, the proportionality factor depending on the amount of total diffused light. In the specular part light coherence is kept, resulting in interference effects when the TCO is more or less flat. However in the diffused part, light coherence with the incident light is assumed lost, so, the point where light is diffused, is considered as a new source emitting in several directions in the stack. The latter light in each direction is assumed to be a plane wave, and each wave, when it meets the next rough interface, is again divided into specular and diffused components. Instead of calculating and successively adding each of these components, the total electromagnetic field is directly derived by the matrix method of Abeles [19-21]. In the model it is possible to consider up to two rough interfaces. These are taken to be the $\mathrm{TCO} / \mathrm{P}$ and $\mathrm{N} /$ metal interfaces in the present case. The complex refractive indices for each layer of the structure are also required as input, and have been measured in-house by spectroscopic ellipsometry. These are presented in Figure 2.

\section{Experimental results and analysis}

Since the aim of this article is to understand the general trend in $\mu \mathrm{c}-\mathrm{Si}: \mathrm{H}$ solar cells, which is that the opencircuit voltage (and the fill factor $(F F)$ to a certain extent) decreases with increasing crystalline volume fraction, as also to understand why the most ordered c-Si PN cell has a higher $V_{o c}$ (Fig. 1), we need to model a variety of output characteristics of $\mu \mathrm{c}-\mathrm{Si}: \mathrm{H}$ cells in order to extract parameters that characterize a representative cell of each series. The first 2 cells of Table 1 follow the general trend, as is obvious from the appreciably lower $V_{o c}$ of the cell with the intermediate crystalline volume fraction. However the fluorinated $\mu \mathrm{c}-\mathrm{Si}: \mathrm{H}$ cell with a very high value of the crystalline volume fraction $\left(F_{c}\right)$ violates this general trend (Tab. 1) and exhibits both higher $V_{o c}$ and $J_{s c}$. It may be noted that this cell has a particularly high large grain fraction, which may have a bearing to its exceptional behavior. The interest in modeling the latter cell is to gain an insight into the possible reasons why the most ordered mono-c-Si PN cell has a higher $V_{o c}$ than $\mu \mathrm{c}-\mathrm{Si}: \mathrm{H}$ cells.

The experimental solar cell output parameters for the "low $F_{c}$ " cell (device A, $F_{c} \sim 79 \%$, no large grain fraction detected), the "intermediate $F_{c}$ " cell (device B, $F_{c} \sim$ $93 \%$, with large grain fraction $\sim 27 \%$ ), and the fluorinated $\mu \mathrm{c}$-Si:H cell $\left(F_{c} \sim 100 \%, F_{l g} \sim 50 \%\right)$ are compared to the 

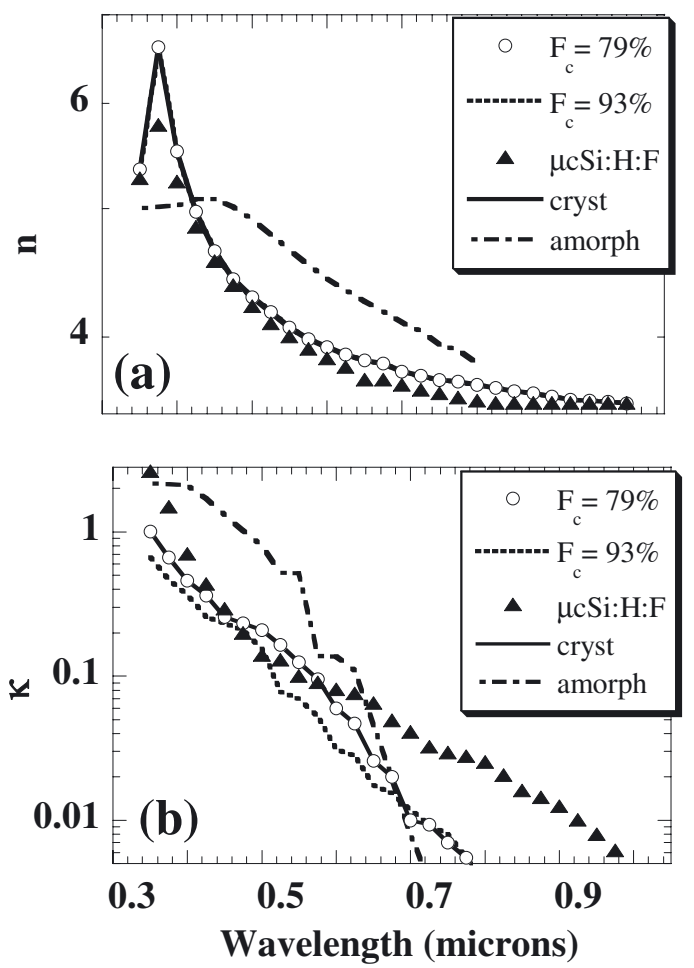

Fig. 2. Values of the complex refractive indices (a) real part, $\mathrm{n}$ and (b) imaginary part, $\kappa$ for low (79\%), intermediate $(93 \%)$ crystalline volume fraction $\left(F_{c}\right) \mu \mathrm{c}-\mathrm{Si}: \mathrm{H}$, and for $\mu \mathrm{c}-\mathrm{Si}: \mathrm{H}: \mathrm{F}, F_{c} \sim 100 \%$, compared to the respective values of a$\mathrm{Si}: \mathrm{H}$ (amorph) and c-Si (crys).

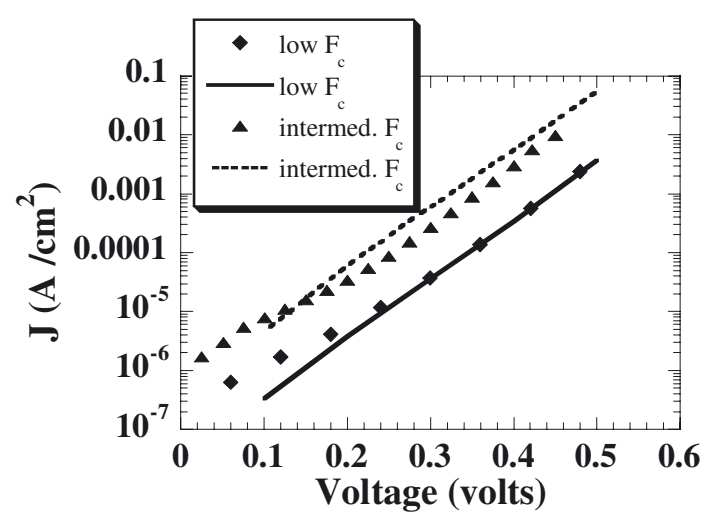

Fig. 3. Calculated dark $J-V$ characteristics of the intermediate $F_{c}$ and low $F_{c} \mu \mathrm{c}$-Si:H cells at $30{ }^{\circ} \mathrm{C}$, compared to experimental results. The lines are our modeling results, while symbols represent experimental measurements.

modeling results in Table 1 . The dark current density vs. voltage $(J-V)$ characteristics of the first two types of cells at $30{ }^{\circ} \mathrm{C}$ have been both measured and simulated, and the good agreement between these results can be noted from Figure 3. Brammer and Stiebig $[22,23]$ have also observed that the dark forward current at low forward voltages is a strong function of the silane concentration (SC) and is lower for higher values of SC, in other words, lower for
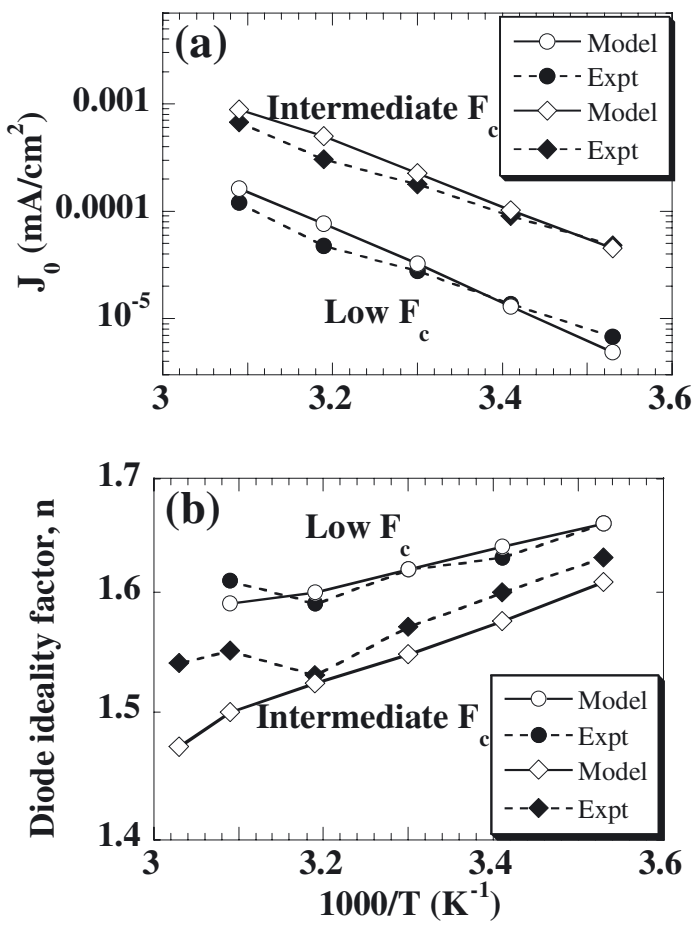

Fig. 4. Calculated values (open symbols) of (a) the reverse saturation current density $\left(J_{0}\right)$ and (b) the diode ideality factor $(n)$ for low and intermediate $F_{c} \mu \mathrm{c}-\mathrm{Si}: \mathrm{H}$ solar cells, compared to experiments (closed symbols) at temperatures from $10{ }^{\circ} \mathrm{C}$ to $50{ }^{\circ} \mathrm{C}$. The lines are guides to the eye.

the lower $F_{c}$ cell, A. This comparison has been done for temperatures from 10 to $50{ }^{\circ} \mathrm{C}$, and the modeled and experimental dark saturation current density $\left(J_{0}\right)$ and diode ideality factor $(n)$ of these cells are presented in Figures $4 \mathrm{a}$ and $4 \mathrm{~b}$. The external quantum efficiency (EQE) curves of all three types of solar cells are compared to their experimental counterparts in Figures $5 \mathrm{a}-5 \mathrm{c}$. The match with experiments appears to be satisfactory.

All experimental results of a particular type of cell $\mu \mathrm{c}-\mathrm{Si}: \mathrm{H}$ cell A, $\mu \mathrm{c}-\mathrm{Si}: \mathrm{H}$ cell B and of the fluorinated $\mu \mathrm{c}-$ Si:H cell - have been simulated with the same set of input parameters, which are given in Table 2. It may be mentioned that the electron and hole mobilities shown in Table 2 and used as input to the modeling program, are the band microscopic mobilities. The drift mobilities measured in actual experiments are the band microscopic mobilities reduced by trapping and de-trapping of carriers, and are therefore one to two orders of magnitude lower. Moreover, we have assumed in general that the carrier mobilities are higher as the material becomes more crystallized. To accurately model all aspects of the experimentally measured solar cell performance, we had to assume that the more crystallized $\mu \mathrm{c}-\mathrm{Si}: \mathrm{H}$ cell B (with however a large grain fraction that is considerably lower than in the highly crystallized fluorinated $\mu \mathrm{c}-\mathrm{Si}: \mathrm{H}$ cell) has a lower band gap, higher carrier mobilities, a higher mid-gap defect density, and broader band tails (Tab. 2) relative to the $\mu \mathrm{c}-\mathrm{Si}: \mathrm{H}$ cell $\mathrm{A}$. We further infer from modeling that the $\mu \mathrm{c}-\mathrm{Si}: \mathrm{H}: \mathrm{F}$ cell $\left(F_{c} \sim 100 \%\right)$ has an even 
M. Nath et al.: Factors limiting the open-circuit voltage in microcrystalline silicon solar cells
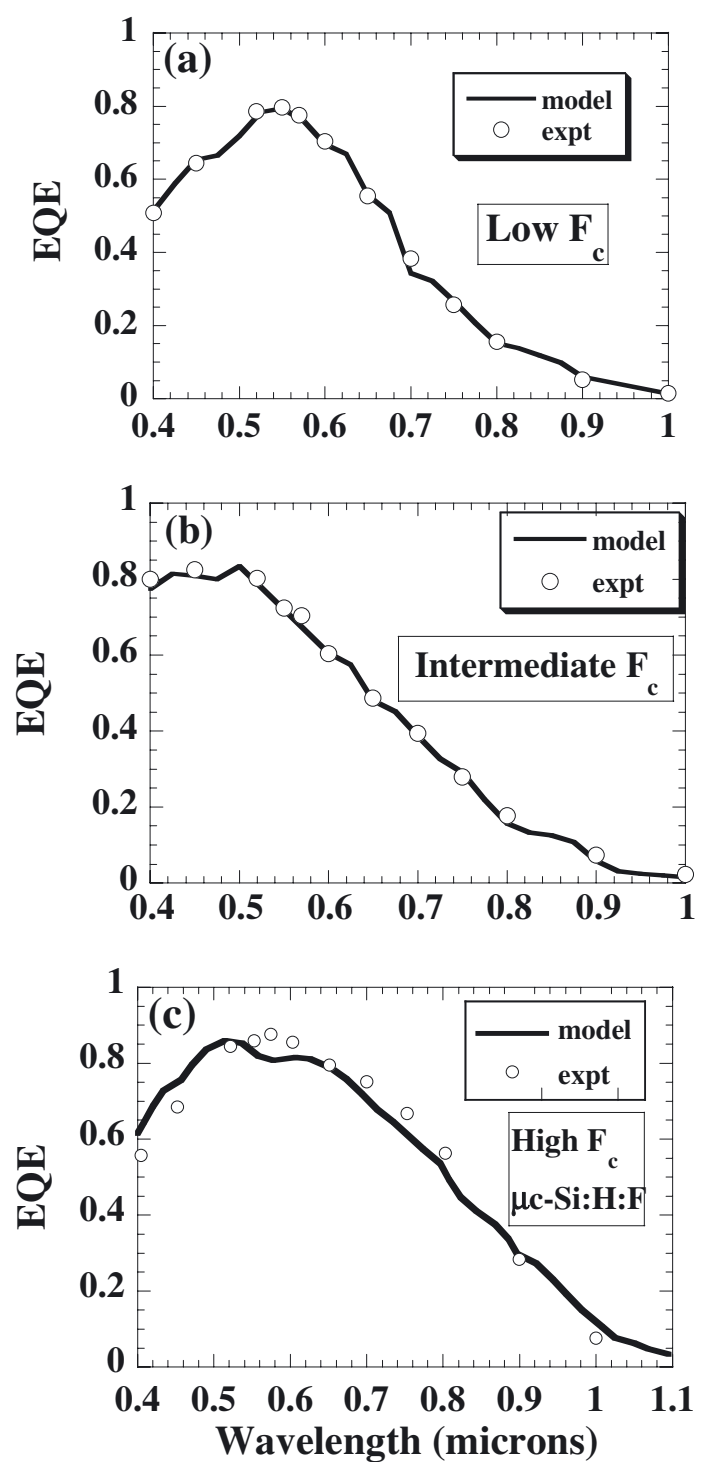

Fig. 5. Calculated external quantum efficiency (EQE) curves under AM1.5 bias light and short-circuit conditions for the (a) low $F_{c} \mu \mathrm{c}-\mathrm{Si}: \mathrm{H}$ cell A, (b) intermediate $F_{c} \mu \mathrm{c}-\mathrm{Si}: \mathrm{H}$ cell B and (c) high $F_{c}$, large grained $\mu \mathrm{c}-\mathrm{Si}: \mathrm{H}: \mathrm{F}$ cell, compared to experimental results.

lower band gap and higher carrier mobilities. This dense material with low oxygen content and very high large grain fraction [5], should have fewer grain boundaries and modeling indicates that it has a sharply reduced dangling bond defect density and effective density of states at the band edges, the latter similar to c-Si. (Tab. 2). Only its valence and conduction band tails appear to be fairly broad (the characteristic energies are $40 \mathrm{meV}$ and $20 \mathrm{meV}$ respectively for the valence and conduction band tails, as in the case of the intermediate $F_{c} \mu \mathrm{c}-\mathrm{Si}: \mathrm{H}$ cell B). This implies that this highly crystallized material nevertheless has a strained lattice. Justification of the parameters inferred from modeling that characterize the different types of cells (Tab. 2) will be presented in Section 6 .
However, it maybe relevant at this point to compare the parameters extracted by the present modeling (Tab. 2) to some other modeling results in the literature. Strengers et al. [24] and Sturiale et al. [25] have modeled the dark and illuminated $J-V$ characteristics of $\mu$ c-Si solar cells, where the intrinsic layer is deposited by the hot wire CVD (HWCVD) technique. They have observed [24] that in these samples the optical absorption in the red region is much higher than in amorphous silicon. Since the optical absorption is related to the imaginary part of the complex refractive index $(\kappa)$ and our Figure $2 \mathrm{~b}$ indicates that this is the case for our $\mu \mathrm{c}-\mathrm{Si}: \mathrm{H}: \mathrm{F}$ samples, it is reasonable to compare the parameters used in their modeling of HWCVD deposited $\mu \mathrm{c}$-Si cells to those of our highest $F_{c} \mu \mathrm{c}-\mathrm{Si}: \mathrm{H}: \mathrm{F}$ cell. The comparison is shown in Table 2 in brackets with asterisks. We note that the values of references $[24,25]$ are quite close to what we have assumed for our $\mu \mathrm{c}-\mathrm{Si}: \mathrm{H}: \mathrm{F}$ I-layer. In particular the effective DOS in the valence and conduction bands; as well as the tail prefactors $G_{D 0}, G_{A 0}$ are similar to ours and an order of magnitude lower than those normally assumed for hydrogenated amorphous silicon and also assumed for the low (A) and intermediate (B) $F_{c} \mu \mathrm{c}-\mathrm{Si}$ :H I-layers here, for reasons to be justified in Section 6. The mid gap defect density is $\sim 10^{15} \mathrm{~cm}^{-3}$, also like our value for $\mu \mathrm{c}-\mathrm{Si}: \mathrm{H}: \mathrm{F}$ and the band gap of $1.25 \mathrm{eV}$ is close to ours, and higher than that of c-Si $(1.12 \mathrm{eV})$. Only the capture cross-sections of the dangling bond states are more than two orders of magnitude higher than our case. Probably this had to be assumed for the HWCVD $\mu \mathrm{c}-\mathrm{Si}$ I-layers $[24,25]$ since the current density from these devices $\left(13-16 \mathrm{~mA} \mathrm{~cm}^{-2}-22\right)$ is much lower than ours $\left(23.20 \mathrm{~mA} \mathrm{~cm}^{-2}\right)$ for comparable values of the absorption coefficients. On the other hand, our average mid gap defect density is the same and their capture cross-sections in the highest $F_{\mathrm{c}} \mu \mathrm{c}-\mathrm{Si}$ :H I-layer are much closer to the values extracted from modeling the dark $J-V$ characteristics of PECVD $\mu$ c-Si I layers in reference [22].

We had also attempted to model the experimental characteristics of the "intermediate $F_{c}$ " cell B, without decreasing the mobility gap, and thus by increasing the gap state defect density alone. This is because, Yan et al. [26] have mentioned without employing detailed modeling to support their statement, that this decrease of $V_{o c}$ is due to distorted bonds in the grain boundary regions that lead to increased band gap defects. Modeling however reveals that a Gaussian defect density of some $\sim 6 \times 10^{17} \mathrm{~cm}^{-3}$ must be assumed to match the low $V_{o c}$ in this case, which also causes a sharp fall in the short-circuit current density $\left(J_{s c}\right)$ and fill factor $(F F)$, resulting in our determination that all aspects of the solar cell output characteristics of cell B cannot be matched by increasing the band gap defect density alone.

Modeling of the EQE curves in Figure $5 \mathrm{a}$ and $5 \mathrm{~b}$ suggests that the P-layer in the intermediate $F_{c}$ cell B is thinner than that in the low $F_{c}$ cell, although the P-layers in all types of cell were deposited under the same experimental conditions. This means that some etching of this layer occurred during the subsequent I-layer deposition for 
Table 2. Parameters that characterize intrinsic $\mu \mathrm{c}-\mathrm{Si}: \mathrm{H}$ of different degree of crystallinity (as extracted by modeling). The quantities in brackets marked with asterisks in the column of parameters of $\mu \mathrm{c}-\mathrm{Si}: \mathrm{H}: \mathrm{F}$ correspond to the values extracted by modeling similar $\mu \mathrm{c}-\mathrm{Si}$ :H samples (refs TSF, JAP of Rubinelli).

\begin{tabular}{|c|c|c|c|}
\hline Parameters & $\begin{array}{c}\mu \mathrm{c}-\mathrm{Si}: \mathrm{H}(\mathrm{A}) \\
\left(F_{c}=79 \%\right)\end{array}$ & $\begin{array}{l}\mu \mathrm{c} \text { Si:H }(\mathrm{B}) \\
\left(F_{c}=93 \%\right)\end{array}$ & $\begin{array}{c}\mu \mathrm{c}-\mathrm{Si}: \mathrm{H}: \mathrm{F} \\
\left(F_{c}=100 \%\right)\end{array}$ \\
\hline Thickness $(\mu \mathrm{m})$ & 0.77 & 0.84 & 1.50 \\
\hline Mob. gap $\left(E_{\mu}\right)(\mathrm{eV})$ & 1.4 & 1.33 & $1.2(1.25-1.32)^{*}$ \\
\hline Elec. affinity (eV) & 4.0 & 4.0 & 4.2 \\
\hline Eff. DOS in bands $N_{c}$ & $2 \times 10^{20}$ & $2 \times 10^{20}$ & $2.8 \times 10^{19}\left(3 \times 10^{19}\right)^{*}$ \\
\hline$\left(\mathrm{cm}^{-3}\right) N_{v}$ & $2 \times 10^{20}$ & $2 \times 10^{20}$ & $1.04 \times 10^{19}\left(3 \times 10^{19}\right)^{*}$ \\
\hline Charac. En. $E_{D}\left(E_{A}\right)(\mathrm{meV})$ & $20(10)$ & $40(20)$ & $40(20)(35(23))^{*}$ \\
\hline$G_{\mathrm{D} 0}, G_{A 0}\left(\mathrm{~cm}^{-3} \mathrm{eV}^{-1}\right)$ & $4.0 \times 10^{21}$ & $4.0 \times 10^{21}$ & $3.0 \times 10^{20}\left(2 \times 10^{20}\right)^{*}$ \\
\hline Elec. (hole) mobility & $32(8)$ & $120(30)$ & $200(50)$ \\
\hline$\left(\mathrm{cm}^{2} / \mathrm{Vs}\right)$ & & & $(120-150(40-75))^{*}$ \\
\hline Gaussian defect den. $\left(\mathrm{cm}^{-3}\right)$ & $4.0 \times 10^{16}$ & $8.0 \times 10^{16}$ & $1.0 \times 10^{15}\left(2.5-3.75 \times 10^{15}\right)^{*}$ \\
\hline Gaussian $\sigma$ charged & $10^{-15}$ & $10^{-15}$ & $10^{-16}\left(6 \times 10^{-14}\right)^{*}$ \\
\hline Neutral & $10^{-16}$ & $10^{-16}$ & $10^{-17}\left(6 \times 10^{-15}\right)^{*}$ \\
\hline Tail $\sigma$ charged & $10^{-15}$ & $10^{-15}$ & $10^{-15}\left(10^{-15}\right)^{*}$ \\
\hline Neutral & $10^{-16}$ & $10^{-16}$ & $10^{-16}\left(10^{-17}\right)^{*}$ \\
\hline
\end{tabular}

the intermediate $F_{c}$ case. This is not surprising, since to obtain the more crystallized $\mu \mathrm{c}-\mathrm{Si}: \mathrm{H}$ layer a higher hydrogen dilution was employed. Also, the $\mathrm{P} / \mathrm{I}$ interface layer is both thinner and demonstrates lower capture crosssections than in the case of the low $F_{c} \mu \mathrm{c}-\mathrm{Si}: \mathrm{H}$ cell. These factors combine to yield the very high blue response in the case of the intermediate $F_{c} \mu \mathrm{c}-\mathrm{Si}: \mathrm{H}$ solar cell (Fig. 5b). An interface layer is expected when the I-layer is deposited on top of the P-layer, as occurs in a PIN device deposition process. Hence, physically one might expect a thinner interfacial layer in the intermediate $F_{c}$ I-layer case, since the band gap mismatch between its I-layer $\left(E_{g}=1.33 \mathrm{eV}\right)$ and the highly crystallized P-layer $\left(E_{g}=1.2 \mathrm{eV}\right.$, deposition parameters same for both cells) is smaller than for the low $F_{c} \mu \mathrm{c}-\mathrm{Si}: \mathrm{H}$ solar cell (I-layer band gap $1.4 \mathrm{eV}$ ).

\section{Discussion}

As already stated in the previous section the intermediate $F_{c} \mu \mathrm{c}-\mathrm{Si}: \mathrm{H}$ cell $\mathrm{B}$ has higher carrier mobilities, a higher dangling bond defect density, broader band tails and lower band gap than $\mu \mathrm{c}-\mathrm{Si}: \mathrm{H}$ cell type A, having the lowest crystalline volume fraction (Tabs. 1, 2). It is a combination of these factors that results in cell $\mathrm{B}$ having a higher current density but lower $V_{o c}, F F$ and conversion efficiency relative to cell $\mathrm{A}$. In the following we will study how the higher gap defect density and lower band gap affect cell performance. In studying the sensitivity of $\mu \mathrm{c}-\mathrm{Si}: \mathrm{H}$ cell performance to each of the above-mentioned parameters, all other parameters are held constant at the values of the $\mu \mathrm{c}-\mathrm{Si}$ :H cell, type A having the lowest $F_{c}$, which we may call our reference case.

\subsection{Effect of changes in the I-layer band gap defects on the photovoltaic response}

\subsubsection{Sensitivity to the characteristic energy of the band tails}

The $\mu \mathrm{c}-\mathrm{Si}: \mathrm{H}$ cell A (Tab. 2) presents values for the characteristic energy of the valence and conduction band tails of $E_{D}=20 \mathrm{meV}$ and $E_{A}=10 \mathrm{meV}$, respectively. To model the intermediate $F_{c}$ cell $\mathrm{B}$, one of the changes that we had to assume was broader band tails, as characterized by $E_{D}=40 \mathrm{meV}$ and $E_{A}=20 \mathrm{meV}$. Figure 6a depicts the illuminated $J-V$ characteristics for two cases differing only in the characteristic energy of the band tails and indicating a fall of $V_{o c}$ by $\sim 0.03 \mathrm{~V}$ when the band tails broaden. Figure $6 \mathrm{~b}$ plots the electric field in the two devices, with the high field at the $\mathrm{P} / \mathrm{I}$ interface shown in a different scale in the inset. We find that higher photo-generated hole trapping in the broader valence band tail near the $\mathrm{P} / \mathrm{I}$ interface, where the quasi-Fermi level lies close to the valence band, results in a stronger electric field near this interface, and a consequent fall of the field in the volume of the absorber layer. This fact is known [15], to bring down the open-circuit voltage.

\subsubsection{Sensitivity to the Gaussian defect density}

Again, using as reference the case of the lowest $F_{c} \mu \mathrm{c}-$ $\mathrm{Si}: \mathrm{H}$ cell type A with parameters as given in Table 2, we have studied the impact of an increase in only the Gaussian defect density starting from a value of $4 \times$ $10^{16} \mathrm{~cm}^{-3}$, characteristic of cell A, to $8 \times 10^{16} \mathrm{~cm}^{-3}$, inferred from modeling of the $\mu \mathrm{c}-\mathrm{Si}: \mathrm{H}$ cell $\mathrm{B}$. This leads to 
M. Nath et al.: Factors limiting the open-circuit voltage in microcrystalline silicon solar cells
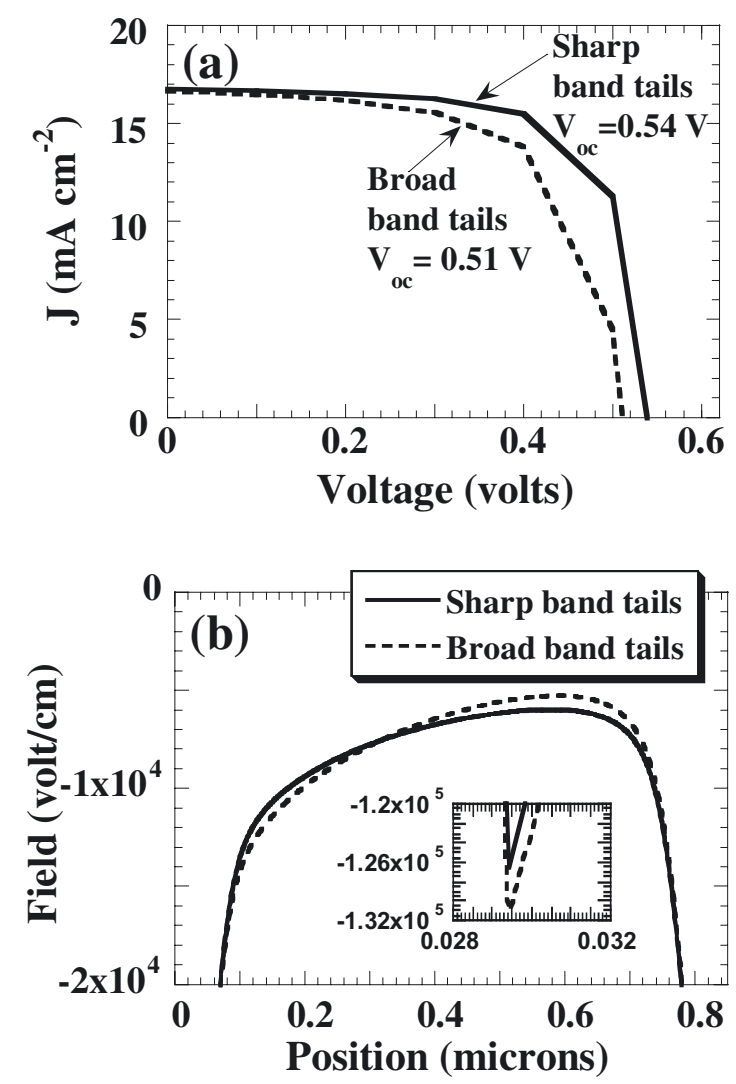

Fig. 6. (a) Sensitivity of the illuminated $J-V$ characteristic to the valence and conduction band tail characteristic energies and (b) the electric field in the device when the band tails are sharp (characteristics energies of band tails $E_{D}, E_{A}=20 \mathrm{meV}$, $10 \mathrm{meV}$ respectively, characteristic of $\mu \mathrm{c}-\mathrm{Si}: \mathrm{H}$ cell type (A) and when they are broader $\left(E_{D}, E_{A}=40 \mathrm{meV}, 20 \mathrm{meV}\right.$ respectively, characteristic of cell type (B). The electric field over the $\mathrm{P} / \mathrm{I}$ interface region is plotted on a different scale in the inset.

a decrease in $V_{o c}$ from $0.54 \mathrm{~V}$ down to $0.52 \mathrm{~V}$ and an increase in the dark saturation current $J_{0}$ from $1.15 \times$ $10^{-5} \mathrm{~mA} / \mathrm{cm}^{2}$ up to $8.35 \times 10^{-5} \mathrm{~mA} / \mathrm{cm}^{2}$. We again find that a higher field near the $\mathrm{P} / \mathrm{I}$ interface due to higher photo-generated hole trapping for the case having higher mid gap DOS is responsible for the collapse in the bulk electric field and the fall in $V_{o c}$.

We may confirm our inferences above (obtained by detailed modeling using ASDMP) regarding a lower $V_{o c}$ in the cell having a higher defect density by considering the approximate analytical formula which ignores the shunt and series resistances:-

$$
V_{o c}=(n k T / q) \ln \left[\left(J_{s c} / J_{0}\right)+1\right] .
$$

Here $n$ is the diode ideality factor, $J_{0}$ the dark saturation current density, $q$ the electronic charge and $T$ the absolute temperature. It indicates that as the dark reverse saturation current density $J_{0}$ increases, $V_{o c}$ decreases. We indeed find that $J_{0}$ is increased by a higher mid gap defect density, and that this corresponds to a lower $V_{o c}$, in agreement with equation (1).

\subsection{Effect of the band gap on the open-circuit voltage}

As has already been stated, in order to model all aspects of the dark and illuminated characteristics of the intermediate $F_{c} \mu \mathrm{c}-\mathrm{Si}: \mathrm{H}$ cell B (Tab. 1 ), one of our assumptions was a lower mobility band gap in this material (Tab. 2) relative to case A having a lower crystalline volume fraction. In Table 4 we compare the $J-V$ parameters of two $\mu \mathrm{c}-\mathrm{Si}: \mathrm{H}$ solar cells having exactly the same parameters as the lowest $F_{c} \mu \mathrm{c}-\mathrm{Si}: \mathrm{H}$ cell A (Tab. 2), except that in one case (named "high $E_{g}$ ") the I-layer band gap is $1.4 \mathrm{eV}$ (the value used to model the lowest $F_{c}$ cell A, Tab. 2), while in the other case (named "low $E_{g}$ ") the I- $\mu \mathrm{c}-\mathrm{Si}: \mathrm{H}$ band gap is $1.33 \mathrm{eV}$, the value required to simulate the intermediate $F_{c}$ cell B (Tab. 2). As a result we observe a drop in $V_{o c}$ from $0.54 \mathrm{~V}$ down to $0.50 \mathrm{~V}$, accompanied by a factor of 10 increase in $J_{o}$, while the $J_{s c}$ and $F F$ are practically not affected.

As mentioned already, all parameters for the low and high " $E_{g}$ " cells, as also the light absorbed in every segment of the cells, have been assumed the same for the two cases that differ only in the band gap. Nevertheless, modeling reveals that to accommodate the difference in the band gap between the two cells, both the quasi-Fermi level separation and the distance of the Fermi levels from the band edges are less for the case of the cell with a lower intrinsic layer band gap. This latter fact results in a higher free carrier density in the bands as quantified by the following expressions of the free carrier densities:

$$
\begin{aligned}
n & =N_{C} \exp -\left[E_{C}-E_{F_{n}}\right] / k T \\
p & =N_{V} \exp -\left[E_{F_{p}}-E_{V}\right] / k T .
\end{aligned}
$$

The trapped carrier density at any point in the device depends on the corresponding free carrier density, the defect density at that location as well as the relative values of the charged and neutral capture cross-sections of these defect states. Hence all else remaining the same, an increase of the free carrier density due to a lowering of the band gap, results in increased carrier trapping in the defect states. As the quasi-Fermi level for holes is closer to the valence band of the intrinsic layer at the P/I interface, the higher free hole density (from Eq. (3)) in the "low $E_{g}$, intermediate $F_{c}$ " cell, results in particularly high hole trapping and hence electric field over the $\mathrm{P} / \mathrm{I}$ interface region, that in a manner similar to Figure $6 \mathrm{~b}$ for the band tail case, leads to a fall of the electric field in the volume of the absorber layer. The latter fact is known [15] to bring down the open-circuit voltage, and explains the lower $V_{o c}$ of the cell having $\mu \mathrm{c}-\mathrm{Si}: \mathrm{H}$ of lower band gap, higher $F_{c}$.

In Sections 5.1 and 5.2 we have analyzed the reasons why a solar cell having a higher crystalline volume fraction $\mu \mathrm{c}-\mathrm{Si}: \mathrm{H}$ intrinsic layer may have a lower $V_{o c}$ by examining specific sets of models. However, as seen in the experimental results (Tab. 1), a $\mu \mathrm{c}$-Si:H cell with a higher $F_{c}$ will show a higher $J_{s c}$, primarily because of higher free carrier mobilities (Tab. 2). Nevertheless, as Table 1 indicates, the energy conversion efficiency for the higher $F_{c} \mu \mathrm{c}-\mathrm{Si}: \mathrm{H}$ cell B is ultimately lower than that of cell $\mathrm{A}$, due to the accompanying reduction in $V_{o c}$ and $F F$. In other words, 
Table 3. The solar cell output of the fluorinated $\mu \mathrm{c}-\mathrm{Si}: \mathrm{H}$ solar cell compared to the output of a hypothetical cell having higher effective DOS at the band edges and higher exponential tail pre-factors.

\begin{tabular}{ccccccc}
\hline Case & $\begin{array}{c}N_{c}, N_{v} \\
\left(\mathrm{~cm}^{-3}\right)\end{array}$ & $\begin{array}{c}G_{D 0}, G_{A 0} \\
\left(\mathrm{~cm}^{-3} \mathrm{eV}^{-1}\right)\end{array}$ & $\begin{array}{c}J_{s c} \\
\left(\mathrm{~mA} \mathrm{~cm}^{-2}\right)\end{array}$ & $\begin{array}{c}V_{o c} \\
(\mathrm{~V})\end{array}$ & $\begin{array}{c}F F \\
\text { Efficiency } \\
(\%)\end{array}$ \\
\hline$\mu$ c-Si:H:F cell & $2.80 \times 10^{19}, 1.04 \times 10^{19}$ & $3.0 \times 10^{20}$ & 22.93 & 0.526 & 0.704 & 8.49 \\
Hypothetical cell, D & $2.0 \times 10^{20}$ & $4.0 \times 10^{21}$ & 22.96 & 0.412 & 0.653 & 6.18 \\
\hline
\end{tabular}

Table 4. The solar cell output parameters of two $\mu \mathrm{c}-\mathrm{Si}: \mathrm{H}$ cells having exactly the same parameters as the lowest $F_{c} \mu \mathrm{c}-\mathrm{Si}: \mathrm{H}$ cell A, except the band gap of the intrinsic material.

\begin{tabular}{cccccc}
\hline $\begin{array}{c}E_{g} \\
(\mathrm{eV})\end{array}$ & $\begin{array}{c}J_{s c} \\
\left(\mathrm{~mA} \mathrm{~cm}^{-2}\right)\end{array}$ & $\begin{array}{c}V_{o c} \\
(\mathrm{~V})\end{array}$ & $F F$ & $\begin{array}{c}\text { Efficiency } \\
(\%)\end{array}$ & $\begin{array}{c}J_{0} \\
\left(\mathrm{~mA} \mathrm{~cm}^{-2}\right)\end{array}$ \\
\hline 1.4 & 16.76 & 0.54 & 0.69 & 6.20 & $1.15 \times 10^{-5}$ \\
1.33 & 16.97 & 0.50 & 0.69 & 5.85 & $1.02 \times 10^{-4}$ \\
\hline
\end{tabular}

due to three interacting effects - higher mid gap and tail defect density and lower band gap - the intermediate $F_{c}$ $\mu \mathrm{c}-\mathrm{Si}: \mathrm{H}$ cell B (Tab. 1) will show a fall in $V_{o c}$ significant enough to cancel the advantage of a higher $J_{s c}$ due to higher carrier mobilities.

We now examine how it is possible for the fluorinated $\mu \mathrm{c}-\mathrm{Si}: \mathrm{H}$ cell having an even higher $F_{c}$, as well as a very high large-grain fraction, to have a higher $V_{o c}$ than the intermediate $F_{c}$ cell $\mathrm{B}$, in spite of a further reduction of its band gap, as predicted by modeling.

\section{3 $\mathrm{V}_{\mathrm{oc}}$ in the highly crystallized large grained $\mu \mathrm{c}-\mathrm{Si} \mathrm{H}: \mathrm{F}$ cell}

So far we have compared the parameters as deduced from modeling (Tab. 2) that characterize the $\mu \mathrm{c}-\mathrm{Si}: \mathrm{H}$ solar cells $\mathrm{A}\left(F_{c}=79 \%\right.$, no large grains detected) and the more crystallized cell B $\left(F_{c}=93 \%, F_{l g}=27 \%\right)$, and explained in Sections 5.1 and 5.2, why the latter shows a lower open-circuit voltage and fill factor than the former. This is normal behavior for $\mu \mathrm{c}-\mathrm{Si}: \mathrm{H}$ cells, as evidenced from numerous experimental observations (Fig. 1) and is the reason why the best $\mu \mathrm{c}-\mathrm{Si}: \mathrm{H}$ solar cells have so far been produced close to the a-Si:H/ $\mu \mathrm{c}-\mathrm{Si}: \mathrm{H}$ transition. However experiments indicate an all-round improvement in the output characteristics of the highly crystallized large grained fluorinated $\mu \mathrm{c}-\mathrm{Si}: \mathrm{H}\left(F_{c} \sim 100 \%, F_{l g} \sim 50 \%\right)$ cell relative to type B $\mu \mathrm{c}-\mathrm{Si}: \mathrm{H}$ cells, indicating that the output properties of this cell violates the general trend of decreasing $V_{o c}$ with increasing crystalline volume fraction (Fig. 1). By modeling its output characteristics (Tab. 1 and Fig. 5c), we have extracted the parameters that characterize this material (Tab. 2). The salient features of the $\mu \mathrm{c}-\mathrm{Si}: \mathrm{H}: \mathrm{F}$ cell parameters are: (a) a reduced band gap compared to $\mu \mathrm{c}-\mathrm{Si}: \mathrm{H}$ cells A and B, (b) higher carrier mobilities, (c) sharply reduced dangling bond defect density, (d) reduced effective DOS at the band edges, that match those of mono-crystalline silicon and (e) higher absorption over a large portion of the longer visible wavelengths compared to low and intermediate $F_{c} \mu \mathrm{c}-\mathrm{Si}: \mathrm{H}$ (Fig. $2 \mathrm{~b}$, the absorption coefficient is proportional to the imaginary part of the complex refractive index $\kappa$ ). The characteristic energies of its band tails however are similar to those of cell B, indicating that this highly crystallized material nevertheless has a strained lattice. The higher absorption and, to a smaller extent the larger carrier mobilities, are responsible for the high current density in this cell (Tab. 1). Assumption of the lowest band gap for this material, having the highest crystalline volume fraction, follows the general trend of the parameters inferred by modeling the output characteristics of the three types of $\mu \mathrm{c}-\mathrm{Si}: \mathrm{H}$ cells (Tab. 2). What is surprising however is that this fact does not lead to a further fall in $V_{o c}$ following the general rule in $\mu \mathrm{c}-\mathrm{Si}: \mathrm{H}$ solar cells (Fig. 1). One reason for this is the sharp fall in the dangling bond defect density in this case that, as described in Section 5.1.2, leads to an improvement of the electric field over the intrinsic layer and increased $V_{o c}$. This fact partially cancels the negative effect of a lower band gap on $V_{o c}$. In the following sub-section we examine the effect of reduced effective DOS at the band edges for the case of the fluorinated $\mu \mathrm{c}-\mathrm{Si}: \mathrm{H}$ I-layer (Tab. 2) and address how this can also partly explain the observed improvement in $V_{o c}$ for this type of cells.

\subsubsection{Sensitivity of $\mathrm{V}_{\mathbf{o c}}$ to the effective DOS at the band edges}

Table 3 compares the solar cell output parameters of the fluorinated $\mu \mathrm{c}-\mathrm{Si}: \mathrm{H}$ cell with that of a hypothetical cell $\mathrm{D}$, having identical parameters as the former, except that the effective DOS at the band edges in cell D are like those in hydrogenated amorphous silicon (a-Si:H) or the other $\mu \mathrm{c}-\mathrm{Si}: \mathrm{H}$ cells A and B. In other words $N_{c}, N_{v}$ for cell $\mathrm{D}$ are $2 \times 10^{20} \mathrm{~cm}^{-3}$, while they are $2.8 \times 10^{19} \mathrm{~cm}^{-3}$ and $1.04 \times 10^{19} \mathrm{~cm}^{-3}$ for $N_{c}, N_{v}$ respectively for fluorinated $\mu \mathrm{c}-\mathrm{Si}: \mathrm{H}$ (Tab. 2). Note that the exponential band tail prefactors are related to the $N_{c}, N_{v}$ via the relations:

$$
G_{A 0} \sim N_{c} / k T ; \quad G_{D 0} \sim N_{v} / k T
$$


so that a fall in $N_{c}, N_{v}$ automatically reduces $G_{A 0}$ and $G_{D 0}$. This impacts on the tail defect density according to the relations:

$$
\begin{aligned}
& g_{A}=G_{A 0} \exp \left(-E / E_{A}\right) \\
& g_{D}=G_{D 0} \exp \left(-E^{\prime} / E_{D}\right),
\end{aligned}
$$

where $g_{A}, g_{D}$ are the tail defect densities $\left(\mathrm{cm}^{-3} \mathrm{eV}^{-1}\right)$ at energy locations $E$ and $E^{\prime}$ respectively from the conduction and valence band edges; and $E_{A}$ and $E_{D}$ are the characteristic energies of the respective band tails. Thus reduced $N_{c(v)}$ lead to reduced band tail defect density, even for the same values of the characteristic energies of the band tails. We thus note that although the fluorinated $\mu \mathrm{c}-\mathrm{Si}: \mathrm{H}$ cell has the same values of $E_{D}$ and $E_{A}$ as the $\mu \mathrm{c}-$ $\mathrm{Si}: \mathrm{H}$ cell B (Tab. 2), the band tail defect density is smaller for the former. This then is one reason for the higher opencircuit voltage for this case relative to cell B (Tab. 1), according to the arguments presented in Section 5.1.1.

The position of the Fermi-level is determined by the relaxation, trapping, and recombination dynamics of the photo-generated carriers, and thus for a given density of free-carriers, a greater quasi-Fermi level separation can be achieved with a lower $N_{c(v)}$ (from Eqs. (2), (3)) and a higher $V_{o c}$ will result. Also lower $N_{c(v)}$ means lower free - and therefore trapped carrier densities - for a given quasi-Fermi level separation (Eqs. (2), (3)). Lower values of trapped carrier densities lead to lower $\mathrm{P} / \mathrm{I}$ interface field and hence more field penetration into the bulk of the device (as explained in Sect. 5.2); therefore [15] an improved $V_{o c}$. Table 3 indicates large improvements in $V_{o c}$ and $F F$ possible as a consequence of the fall in $N_{c}, N_{v}$. We thus conclude that the fluorinated $\mu \mathrm{c}-\mathrm{Si}: \mathrm{H}$ cell has a higher $V_{o c}$ and FF relative to the $\mu \mathrm{c}-\mathrm{Si}: \mathrm{H}$ cell B, because the combined effect of a lower dangling bond DOS, a lower effective DOS at the band edges and lower exponential tail pre-factors, overcome the negative influence of its reduced band gap.

\section{4 $\mathrm{V}_{\mathrm{oc}}$ in crystalline silicon PN solar cells}

The original aim of this article was to investigate the general trend in $\mu \mathrm{c}-\mathrm{Si}: \mathrm{H}$ solar cells, which is that their open-circuit voltage decreases with increasing crystalline volume fraction (Fig. 1) and our modeling has indicated that one of the principal reasons for this is the lower energy band gap (Sect. 5.2) in more crystallized material. Crystalline silicon (c-Si) has a band gap of only $1.12 \mathrm{eV}$, so all else being equal, it should produce cells with an even lower $V_{o c}$. However, the typical $V_{o c}$ of c-Si solar cells is higher than in those of good quality $\mu \mathrm{c}-\mathrm{Si}: \mathrm{H}$ and typically lies between $0.55 \mathrm{~V}$ and $0.6 \mathrm{~V}$ [6], while world record c-Si cells possess a $V_{o c}$ above $0.7 \mathrm{~V}[27]$. Fortunately we have been able to produce in our laboratory a series of $\mu \mathrm{c}-\mathrm{Si}: \mathrm{H}$ solar cells - the fluorinated $\mu \mathrm{c}-\mathrm{Si}: \mathrm{H}$ series of cells - that violate the observed general trend in $\mu \mathrm{c}-\mathrm{Si}: \mathrm{H}$ cells (Fig. 1) and exhibit a higher $V_{o c}$, in spite of having a lower energy band gap. This series has therefore provided the necessary insight to explain why the limiting case of c-Si solar cells can possess higher $V_{o c}$ in spite of a strongly reduced band gap. In the previous sub-section we have shown for the case of $\mu \mathrm{c}-\mathrm{Si}: \mathrm{H}: \mathrm{F}$, that the higher $V_{o c}$ in spite of a reduced band gap was made possible by sharply reduced dangling bond (DB) and tail defects, as well as reduced effective DOS at the band edges. We have assumed the effective DOS at the band edges in $\mu \mathrm{c}-\mathrm{Si}: \mathrm{H}: \mathrm{F}$ to be similar to the low values of c-Si. Moreover, c-Si has a DB DOS that is three orders of magnitude lower than even the relatively low mid-gap DOS of $\mu \mathrm{c}-\mathrm{Si}: \mathrm{H}: \mathrm{F}$ (Tab. 2), and the tail states are absent. Therefore it is now only to be expected that c-Si solar cells will have higher $V_{o c}$ and $F F$ than those of the $\mu \mathrm{c}-\mathrm{Si}: \mathrm{H}: \mathrm{F}$ cells, which are indeed far superior to those observed in highly crystalline $\mu \mathrm{c}-\mathrm{Si}: \mathrm{H}$ cells (example cell B in Tabs. 1 and 2), obeying the general trend of $V_{o c}$ as a function of the crystalline volume fraction (Fig. 1).

\section{Justification of the parameters deduced by modeling in the three types of $\mu \mathrm{c}-\mathrm{Si}: \mathrm{H}$ solar cells studied}

Table 2 shows the parameters that characterize the intrinsic layers of the low $F_{c} \mu \mathrm{c}-\mathrm{Si}: \mathrm{H}$ series of cells A, the intermediate $F_{c}$ cell series B and the large grained high $F_{c}$ fluorinated $\mu \mathrm{c}-\mathrm{Si}: \mathrm{H}$ solar cells as inferred by modeling their output characteristics. These indicate that the intermediate $F_{c} \mu \mathrm{c}-\mathrm{Si}: \mathrm{H}$ cell $\mathrm{B}$, has a lower band gap, higher carrier mobilities, and both higher mid-gap defect density and broader band tails as compared to the cell having low $F_{c} \mu \mathrm{c}-\mathrm{Si}: \mathrm{H}$ A. In order to simulate the improved cell performance (Tab. 1) of the $\mu \mathrm{c}-\mathrm{Si}: \mathrm{H}: \mathrm{F}$ cell, we had to assume even higher carrier mobilities, lower mid-gap defects and lower effective DOS at the band edges (similar to crystalline silicon), while its band gap was assumed to be smaller than that of cells of type B. We have throughout assumed higher carrier mobilities for more crystallized materials. The presence of a significant fraction of large grains in a material produced by PECVD at $175{ }^{\circ} \mathrm{C}$ has been shown to correlate with improved transport properties of the films [28], and in particular we have shown elsewhere that the electron mobility as measured by time resolved microwave conductivity, increases with the fraction of large grains [28].

We have assumed a decreasing band gap with increasing crystalline volume fraction. This assumption is wellsupported by reports from the literature. For example, Delley and Steigmeier [29] - who computed the band gap of $\mu \mathrm{c}-\mathrm{Si}: \mathrm{H}$ as a function of cluster diameter using the density functional approach for finite structures - have shown that the band gap of $\mu \mathrm{c}-\mathrm{Si}: \mathrm{H}$ increases as the cluster size decreases. A higher band gap for less-crystallized $\mu \mathrm{c}-\mathrm{Si}: \mathrm{H}$ was also previously measured by Hamma and Roca i Cabarrocas [30] using in situ Kelvin probe analysis and the "Flat Band Heterojunction" technique. Merdzhanova et al. [31] have studied the photoluminescence (PL) in thin film $\mu \mathrm{c}-\mathrm{Si}: H$ PIN solar cells deposited by the Hot wire chemical vapor deposition technique [32] and have 
observed that the PL band shifts to higher energy with decreasing crystalline volume fraction.

Another property that had to be assumed in order to model the experimental characteristics are lower band tail characteristic energies in the $\mu \mathrm{c}-\mathrm{Si}: \mathrm{H}$ film of the lowest $F_{c}$, the absorber layer in cell A (Tab. 2). This assumption is also supported by experimental evidence, such as the previously cited work of Merdzhanova et al. [31]. Their assumption that PL originates from transitions between localized band tail states indicates that less-crystallized $\mu \mathrm{c}-\mathrm{Si}: \mathrm{H}$ has sharper band tails. Additionally, $\mu \mathrm{c}-\mathrm{Si}: \mathrm{H}$ films with lower $F_{c}$ are expected to have a larger fraction of hydrogenated amorphous silicon (a-Si:H), which encourages structural relaxation of the $\mu \mathrm{c}-\mathrm{Si}: \mathrm{H}$ network [31], thus giving rise to less strained films with sharper band tails. Since a-Si:H is also expected to passivate grain boundary defects, our additional assumption of a lower Gaussian defect density for the least crystallized $\mu \mathrm{c}-\mathrm{Si}: \mathrm{H}$ in cell A (Tab. 2), compared to the more crystallized I-layer in cell $\mathrm{B}$, also appears to be justified.

However it may be noted that while the intermediate $F_{c} \mu \mathrm{c}-\mathrm{Si}: \mathrm{H}$ I-layer $\mathrm{B}$ is predicted to have a higher DB defect density, compared to the less crystallized I-layer A, modeling the highly crystallized fluorinated solar cell requires a sharp decrease of this defect density. To understand this, we first note that although the intermediate $F_{c}\left(F_{c}=93 \%\right)$ I-layer B (Tab. 2) has a high crystalline volume fraction, its large grain fraction $F_{l g}$ is considerably lower than in the case of $\mu \mathrm{c}-\mathrm{Si}: \mathrm{H}: \mathrm{F}$. High $F_{c}$ with low $F_{l g}$ implies the presence of a large number of tiny crystallites and hence many grain boundaries, with a higher probability of defects. Additionally this material B, with a high $F_{c}$, possesses a low amorphous fraction $\left(F_{a}\right)$. The latter is known to passivate grain boundary defects. Thus a large number of grain boundaries, together with a low $F_{a}$ would necessarily lead to a high number of DB defects. Also more crystallized $\mu \mathrm{c}-\mathrm{Si}: \mathrm{H}$ (case B, Tab. 2) is known to have a fairly large oxygen content [33]. One possibility is that this oxygen occupies substitutional sites in the $\mu \mathrm{c}-\mathrm{Si}: \mathrm{H}$ lattice and produces N-type doping. However any appreciable doping of an intrinsic layer of a solar cell containing band gap defects where carriers can be trapped, would lead to sharp interface fields, weak penetration of field and flat bands in the volume of the intrinsic layer resulting in high recombination that should strongly reduce the current. This is not observed in the $\mu \mathrm{c}-\mathrm{Si}: \mathrm{H}$ cells studied (Tab. 1), thus excluding the possibility of oxygen producing any appreciable doping in the $\mu \mathrm{c}-\mathrm{Si}: \mathrm{H}$ cell B. These oxygen atoms, which are probably located at grain boundaries, therefore produce defects in this material leading to a higher DB DOS in the more crystallized I-layer B (Tab. 2). On the other hand fluorinated $\mu \mathrm{c}-\mathrm{Si}: \mathrm{H}$ has not only a high crystalline volume fraction but also a high fraction of large grains resulting in fewer grain boundaries and therefore less grain boundary defects. Also, the use of $\mathrm{SiF}_{4}$ as gas precursors allows to reduce the concentration of oxygen leading to a dense large grained material with low defects [28] and justifies the sharply reduced defect density in this material as inferred from modeling
(Tab. 2), that is consistent with the enhanced electronic properties of this material [28].

\subsection{Band-edge effective DOS $\left(N_{c}, N_{v}\right)$ in amorphous and microcrystalline solids}

We have underlined in Sections 5.3.1 and 5.4 that a key factor for improving the open-circuit voltage in the large grained fluorinated $\mu \mathrm{c}-\mathrm{Si}: \mathrm{H}$ and c-Si PN cells is the reduced band edge effective DOS $\left(N_{c(v)}\right)$, lower by nearly an order of magnitude compared to amorphous and disordered $\mu \mathrm{c}-\mathrm{Si}: \mathrm{H}$ (I-layers A and B, Tab. 2). However, the reason behind the higher $N_{c(v)}$ in disordered silicon has not yet been addressed. To do so, it must first be noted that the effective DOS at the valence band edge $\left(N_{v}\right)$ is calculated from the relationship satisfying:

$$
\int_{-\infty}^{E_{V}} \operatorname{DOS}(E) e^{-\left(E_{F}-E\right) / k T} d E \approx N_{v} e^{-\left(E_{F}-E_{V}\right) / k T}
$$

and similarly for $N_{c}$, assuming that the Fermi level $E_{F}$ is sufficiently far away from the valence band to approximate the Fermi distribution with the exponential relationship shown. Because $N_{v}$ is calculated using the product of the true DOS with the Fermi distribution of holes, the states closer to the band-edge influence the value of $N_{v}$ more strongly than those far from the edge. For this reason, the shifting of states towards the band-edge will increase $N_{v}$, though the absolute number of states may not change.

Theoretical evidence strongly suggests that such a shifting of states closer to the band edges occurs when a tetrahedrally bonded crystalline solid is amorphized. Solving the appropriate Bethe lattice for amorphous silicon, Joannopoulos $[34,35]$ showed a significant shifting of the DOS towards the band-edge. The tight-binding Hamiltonian used showed that the shift was particularly great for the P-like states at the valence band edge $[34,35]$ and also accounted for the steepening of the valence band edge density-of-states with disorder as observed in X-ray photoemission experiments [36]. Using a Continuous Random Network (CRN) model, Singh [37] has also shown that dihedral-angle and topological disorders lead to an increase of the DOS at the valence and conduction band edge respectively. The effect is equally seen when the effect of hydrogen is included. The strain in stretched Si-Si bonds may partially be released by hydrogen incorporation (resulting in hydrogenated amorphous or micro- crystalline silicon, the materials of interest in PIN solar cells), and hence removed from the tails [38]. The addition of hydrogen thus widens the band gap, moving the peak in the valence band DOS closer to the band edge, and increasing $N_{v}$ at the band edge. Monte Carlo calculations examining mixed phase nanocrystalline-amorphous silicon showed that the location of the peak in the valence band DOS is little affected by the addition of a considerable volume fraction of crystalline material [39], although the mid-gap and lower energy DOS were significantly modified. This result indicates that the amorphized fraction has a dominant effect on the location of this peak, and that 
the assumption of higher $N_{c}$ and $N_{v}$ at the band edges, is justified even for microcrystalline silicon with a considerable crystalline volume fraction (in other words for the $\mu \mathrm{c}-\mathrm{Si}: \mathrm{H}$ I-layers A and B, Tab. 2). It should be noted that in going from c-Si to a-Si:H, the peak in the valence band DOS (for example) is not shifted up in absolute terms, but only relative to the relevant mobility/energy gap. It is this relative shift that is important in determining $N_{c(v)}$.

We thus justify the assumption of a higher (by $\sim 1$ order of magnitude) $N_{c(v)}$ for hydrogenated amorphous and $\mu \mathrm{c}-\mathrm{Si}: \mathrm{H}$ I-layers $\mathrm{A}$ and $\mathrm{B}$, relative to $N_{c(v)}$ of c-Si. For the case of the highly crystalline, large-grained $\mu \mathrm{c}-\mathrm{Si}: \mathrm{H}: \mathrm{F}$ I-layer, showing both high $J_{s c}$ and $V_{o c}$, transport measurements [28] revealed an improved electron mobility that we correlate to a reduced defect density, justifying our assumption of a reduced dangling DOS of $10^{15} \mathrm{~cm}^{-3}$ for this material (Tab. 2). However our detailed modeling revealed that with a band gap of only $\sim 1.2 \mathrm{eV}$ (Tab. 2), the high values of $V_{o c}$ measured in this case could not be achieved by a DOS of $10^{15} \mathrm{~cm}^{-3}$ alone, and since this dense large-grained $\mu \mathrm{c}-\mathrm{Si}: \mathrm{H}: \mathrm{F}$, in its properties appears to be very close to mono-c-Si, we assumed $N_{c(v)}$ for this case to be like the latter and were thus able to reproduce all the measured solar cell output (Tab. 2, Fig. 5c). As already discussed similar values of $N_{c(v)}$ have been assumed by other workers in this field $[24,25]$.

\section{Conclusions}

In this article we have simulated the dark and illuminated $J-V$ and quantum efficiency characteristics of typical solar cells having low (case A, Tabs. 1 and 2) and intermediate crystalline volume fraction $\mu \mathrm{c}-\mathrm{Si}: \mathrm{H}$ (case B, Tabs. 1 and 2). The lower $F_{c}$ material A has been assumed to have a higher energy band gap than the intermediate $F_{c}$ material B. Both experimental and modeling results indicate a higher $J_{s c}$ but lower $V_{o c}, F F$ and conversion efficiency for the solar cell based on intermediate $F_{c} \mu \mathrm{c}-\mathrm{Si}: \mathrm{H}$ $\mathrm{B}$ (Tab. 1). In fact the general trend in $\mu \mathrm{c}-\mathrm{Si}: \mathrm{H}$ solar cells is that $V_{o c}$ decreases with increasing $F_{c}$ (Fig. 1). We have analyzed the reasons for this and have found that this can be explained by broader band tails and higher Gaussian defect density in the intermediate $F_{c}$ material B, since structural relaxation of the $\mu \mathrm{c}-\mathrm{Si}: \mathrm{H}$ network and passivation of grain boundary defects cannot properly take place due to the low amorphous silicon content in this well-crystallized material, as well as due to high oxygen content. Another very important factor is the lower band gap of the intermediate $F_{c} \mu \mathrm{c}-\mathrm{Si}: \mathrm{H} \mathrm{B}$, resulting in higher free carrier density in the bands, due to the proximity of the band edges to the quasi-Fermi levels. This leads to higher photo-generated hole trapping, especially near the $\mathrm{P} / \mathrm{I}$ interface, which in turn leads to a collapse of the electric field over the volume and a lower $V_{o c}$.

We have also shown that high $F_{c}$, large grained $\mu \mathrm{c}-$ $\mathrm{Si}: \mathrm{H}: \mathrm{F}$, having low oxygen content, is an exception to this general rule (Fig. 1), since its sharply reduced band gap defect density and lower effective DOS at the band edges overcome the negative influence of the lower band gap to produce a higher $V_{o c}$. In fact fluorinated $\mu \mathrm{c}-\mathrm{Si}: \mathrm{H}$ solar cells serve as a link to explain why c-Si PN solar cells, in spite of having a sharply reduced band gap, can have open-circuit voltages considerably higher than $\mu \mathrm{c}-\mathrm{Si}: \mathrm{H}$ solar cells.

The work at CNRS-LPICM has been partly supported by the European Project "SE Powerfoil" (Project number 038885 SES6). The computer modeling program was developed by P. Chatterjee during the course of a project funded by MNRE and DST, Government of India, and partly during her tenure as Marie Curie fellow at the Laboratoire de Physique des Interfaces et des Couches Minces, Ecole Polytechniuque, Palaiseau, France. E.V. Johnson acknowledges the support of NSERC.

\section{References}

1. Y. Mai, S. Klein, R. Carius, H. Steibig, X. Geng, F. Finger, Appl. Phys. Lett. 87, 073503 (2005)

2. S. Klein, F. Finger, R. Carius, M. Stutzmann, J. Appl. Phys. 98, 024905 (2005)

3. C. Droz, E. Vallat-Sauvain, J. Bailat, L. Feitknecht, J. Meier, A. Shah, Solar Energy Mater. Solar Cells 81, $61(2004)$

4. M. Nath, P. Roca i Cabarrocas, E.V. Jonson, A. Abramos, P. Chatterjee, Thin Solid Films 516, 6974 (2008)

5. M. Moreno, R. Boubekri, P. Roca i Cabarrocas, Solar Energy Mater. Solar Cells, in press (2011).

6. S.M. Sze, Physics of Semiconductor Devices (John Wiley, New York, 1981), p. 807

7. A. Datta, J. Damon-Lacoste, P. Roca i Cabarrocas, P. Chatterjee, Solar Energy Mater. Solar Cells 92, 1500 (2008)

8. E. Maruyama, A. Terakawa, M. Taguchi, Y. Yoshimine, D. Ide, T. Baba, M. Shima, H. Sakata, M. Tanaka, Proceedings 4th World Conf. on Photovoltaic Solar Energy Conversion (Hawaii, USA, IEEE, 2006), pp. 1455-1460

9. P. Chatterjee, M. Favre, F. Leblanc, J. Perrin, Mater. Res. Soc. Symp. Proc. 426, 593 (1996)

10. N. Palit, P. Chatterjee, Solar Energy Mater. Solar Cells 53, 235 (1998)

11. P. Roca i Cabarrocas, J.B. Chévrier, J. Huc, A. Lioret, J.Y. Parey, J.P.M. Schmitt, J. Vac. Sci. Technol. A 9, 2331 (1991)

12. D.A.G. Bruggeman, Ann. Phys. (Leipzig) 24, 636 (1935)

13. P. Roca i Cabarrocas, S. Hamma, A. Hadjadj, J. Bertomeu, J. Andreu, Appl. Phys. Lett. 69, 529 (1996)

14. G.E. Jellison Jr., M.F. Chisholm, S.M. Gorbatkin, Appl. Phys. Lett. 62, 3348 (1993)

15. P. Chatterjee, J. Appl. Phys. 76, 1301 (1994)

16. P. Chatterjee, J. Appl. Phys. 79, 7339 (1996)

17. P.J. McElheny, J.K. Arch, H.-S. Lin, S.J. Fonash, J. Appl. Phys. 64, 1254 (1988)

18. F. Leblanc, J. Perrin, J. Schmitt, J. Appl. Phys. 75, 1074 (1994)

19. H.A. Macleod, Thin Film Optical Filters (Hilger, Bristol, 1986)

20. F. Abeles, Ann. Phys. Paris 5, 596 (1950) 
21. F. Abeles, Ann. Phys. Paris 5, 706 (1950)

22. T. Brammer, H. Stiebig, J. Appl. Phys. 94, 1035 (2003)

23. T. Brammer, H. Stiebig, Mater. Res. Soc. Symp. Proc. 715, $641(2002)$

24. J.J.H. Strengers, F.A. Rubinelli, J.K. Rath, R.E.I. Schropp, Thin Solid Films 501, 291 (2006)

25. A. Sturiale, Hongbo T. Li, J.K. Rath, R.E.I. Schropp, F.A. Rubinelli, J. Appl. Phys. 106, 014502 (2009)

26. B. Yan, G. Yue, J. Yang, A. Banerjee, S. Guha, Mater. Res. Soc. Symp. Proc. 762, 369 (2003)

27. J. Zhao, A. Wang, M.A. Green, Solar Energy Mater. Solar Cells 65, 423 (2001)

28. Y. Djeridane, A. Abramov, P. Roca i Cabarrocas, Thin Solid Films 515, 7451 (2007)

29. B. Delley, E.F. Steigmeier, Phys. Rev. B 47, 1397 (1993)

30. S. Hamma, P. Roca i Cabarrocas, Appl. Phys. Lett. 74, $3218(1999)$
31. T. Merdzhanova, R. Carius, S. Klein, F. Finger, D. Dimova-Malinovska, Thin Solid Films 451-452, 285 (2004)

32. R. Carius, T. Merdzhanova, F. Finger, S. Klein, O. Vettrl, J. Mater. Sci. Mater. Electron. 14, 625 (2003)

33. A. Abramov, P. Roca i Cabarrocas. Phys. Stat. Sol. C 7, $529(2010)$

34. J.D. Joannopoulos, Phys. Rev. B 16, 2764 (1977)

35. J.D. Joannopoulos, J. Non-Cryst. Solids 35-36, 781 (1980)

36. L. Ley, S. Kowalczyk, R. Pollak, D.A. Shirley, Phys. Rev. Lett. 29, 1088 (1972)

37. J. Singh, Phys. Rev. B 23, 4156 (1981)

38. M.E. Eberhart, K.H. Johnson, D. Adler, Phys. Rev. B 26, 3138 (1982)

39. S. Nomura, X. Zhao, Y. Aoyagi, T. Sugano, Phys. Rev. B 54, $13974(1996)$ 